\title{
Assessment of management of a golf course by means of sustainability indicators
}

\author{
Gaio Cesare Pacini, ${ }^{1}$ Nicolina Staglianò, ${ }^{1}$ Francesco Meo, ${ }^{2}$ Giulio Lazzerini, ${ }^{1}$ \\ Concetta Vazzana, ${ }^{1}$ Giovanni Argenti ${ }^{1}$ \\ 'Department of Agri-Food Production and Environmental Sciences, University of Florence, \\ Florence; ${ }^{2}$ Circolo Golf Ugolino, Impruneta (FI), Italy
}

\begin{abstract}
Golf courses are supposed to produce remarkable negative effects on the environment, due to some techniques involved in their management. To provide data useful for the proper assessment of the agroenvironmental sustainability of a golf course, the framework agroenvironmental sustainability information system (AESIS) was used, utilizing a set of indicators suitable to evaluate different dimensions of sustainability (physical, ecological, productive and social). The management of areal golf course located in Tuscany (central Italy) was compared to an alternative land use of the same area represented by an ordinary farm based on a sunflower-wheat rotation. Assessment indicators were selected by applying a conceptual model based on ecology theory and were calculated considering site-specific production and pedo-climatic features of the area. Different weighting scenarios were hypothesized in order to have different management options assessed and to carry out a targeted sensitivity analysis. Main results confirmed the significant impact of golf management on some ecological characteristics but the holistic assessment of AESIS approach permitted an overall evaluation that comprised a wide range of different issues. AESIS demonstrated to be a practical and adaptive tool able to perform an efficient comparison of possible land destinations.
\end{abstract}

\footnotetext{
Correspondence: Gaio Cesare Pacini, Department of Agri-Food Production and Environmental Sciences (DISPAA), University of Florence, P.le delle Cascine 18, 50144 Florence, Italy.

E-mail: gaiocesare.pacini@unifi.it

Key words: Agro-environmental sustainability information system; ecological indicators; management; turfgrass.
}

Conference presentation: SIA XLIV Congress, Bologna, 2015.

Received for publication: 8 February 2016.

Revision received: 24 March 2016.

Accepted for publication: 26 March 2016.

(C) Copyright G.C. Pacini et al., 2016

Licensee PAGEPress, Italy

Italian Journal of Agronomy 2016; 11:768

doi:10.4081/ija.2016.768

This article is distributed under the terms of the Creative Commons Attribution Noncommercial License (by-nc 4.0) which permits any noncommercial use, distribution, and reproduction in any medium, provided the original author(s) and source are credited.

\section{Introduction}

Turfs can be used for technical aims, as those related to erosion prevention and to ecological restoration (Linse et al., 2001; Geren et al., 2009) but they play a major role also in improving the quality of life, especially for amenity and sport purposes (Seppoloni, 2014). In the recent past, great interest has been devoted to research in this field (Seppoloni et al., 2015), and many studies have been carried out to increase knowledge on functioning of these surfaces (Volterrani and Magni, 2007). Studies have been dedicated to characterization of different species and varieties in particular environments (Marchione, 2008; Kir et al., 2010), but many of them have interested the interventions of management of turf, as these practices can produce efficient utilization of performed techniques (Turgeon, 2008) taking into account the minimization of their impact on the environment (Gaetani et al., 2013). Among the main cultural practices with the highest environmental impact, we can include fertilization (Baldi $e t$ al., 2013) and irrigation (Bowman et al., 2002). Fertilization (mainly due to nitrate leaching) is considered one of the most important factor impacting on water quality (Bigelow and Walker, 2008; Trenholm and Sartain, 2010), but many responsibilities are also imputed to excessive use of water (Sevostianova and Leinauer, 2014), and this is of extreme evidence in Mediterranean areas that present hot and dry summers (Seppoloni et al., 2015). So the question is basically to combine efficient use of inputs with maintenance of high quality standards of the turf (Easton and Petrovic, 2005) and this is particularly true for golf courses that occupy great surface in rural area (Piano, 2005) that can alternatively devoted to productive crops. To analyze the effect of technical intensification on the agricultural system (such as turfs), a set of specific indicators can be chosen in order to assess how the intensity of management can affect environment and to compare different systems (Ruiz-Martinez et al., 2015). In this study we used the agroenvironmental sustainability information system (AESIS) (Pacini $e t$ al., 2009; Pacini et al., 2011) to assess the sustainability impact of turf management at the Circolo Golf Ugolino (Florence, Tuscany) and compare results to standard cropping activities of the area. Assessment indicators were selected by applying a conceptual model based on Ecology theory as described in Pacini et al. (2010) and calculated considering site-specific production and pedo-climatic features. While the aim of this study is to show how a truly holistic analysis can disclose sometime underestimated aspects of impact assessment of golf activities, the results of the analysis cannot be trivially generalised to the whole sector as they were inferred from a single case-study. 


\section{Materials and methods}

\section{The Circolo Golf Ugolino, the virtual arable farm and site-specific pedo-climatic characteristics}

The AESIS was applied to Circolo Golf Ugolino (CGU, Impruneta municipality), the most important golf facility of Florence province, also known as the oldest golf club in Italy. Ugolino is located at only 13 $\mathrm{km}$ south of Florence city centre (latitude $44^{\circ} \mathrm{N}$ ) in Chianti, an area that focuses primarily on vine production, with lower surfaces devoted to olive production and arable crops, and a consolidated, flourishing agri-touristic activity. The climate of Chianti is Mediterranean, with an average annual rainfall reaching $865 \mathrm{~mm}$ in the Impruneta municipality. The CGU facility covers 18.0 ha, including green, collar, tee (1.7 ha), fairway, surround, pre-rough (13.0 ha) and rough (3.3 ha), and is surrounded by 12.0 ha of woodland. Soils of different turf typologies are very different because of their management. The most widespread typology of soil is silty sand according to United States Department of Agriculture (USDA) classification (Giardini, 2012), it occurs in all the surface of golf course dedicated to fairways, and this kind of soil was used for the following elaboration concerning the virtual farm (VF) compared to golf course (see hereafter) (USDA-ARS, 2014a, 2014b). Average steepness of these soils is 5\%. On the contrary, on greens the soils are all sandy, with a percentage of sand higher than $90 \%$ mainly due to topdressing performed for many years, and an average steepness of $1 \%$. In order to appreciate the extent of the impacts of turf management at Ugolino indicator results were compared with corresponding results of a virtual arable farm hypothesized on the same CGU area and managed with standard practices. VF hence has pedo-climatic characteristics and total area equal to those of CGU and is featured by the internal Tuscany hilly area typical rotation, i.e. sunflower-wheat, and by a 1.4 ha ecological focus area as indicated by current norms of the common agricultural policy (CAP) greening.

\section{The agro-environmental sustainability information system approach}

In order to assess the sustainability impact of these two alternative land uses in Chianti, i.e. turf and arable crops, we used the AESIS. An in-depth description of AESIS is given in Pacini et al. (2009, 2011). Here, only major AESIS procedural phases are summarized with the aim to recall the AESIS general features and show how it was applied for the current analysis. The main feature of the indicator framework is the importance given to different spatial scales (farm, site and field), to the production and pedo-climatic factors, and to the holistic view of the agro-ecosystem.

The AESIS was aimed at finding the right balance between a range of different application purposes and the level of complexity of indicators. Agro-environmental indicators can be calculated, simulated with models or directly measured with different levels of detail, in proportion to the aims of the evaluation exercise. The procedural phases to apply the framework are reported in Figure 1.

\section{Phase 1. Definition of the sustainability issues}

The AESIS application procedure was initiated with gathering of already available information on the issues related to sustainability in the region and corresponding land use critical points (AESIS sub-phases 1.1 and 1.2). A set of agro-environmental indicators for the quantification of the performance of the management of each environmental and production process in the agro-ecosystem was identified based on a conceptual framework for the evaluation of sustainability of land use options (sub-phase 1.3). The conceptual framework is described in detail in Pacini et al. (2010). It is based on the principle that a truly holistic assessment of land use options for farming system diagnosis and design must take into consideration relevant structural and functional properties of agro-ecosystems backing them together with the physical, ecological, productive and social dimensions of sustainability. The framework was already validated and applied to compare alterna-

\section{DEFINITION OF THE SUSTAINABILITY ISSUES}

\subsection{Identify issues related to sustainability}

1.2. Identify detailed critical points and connect them to agro-ecosystems

1.3. Choose indicators

\section{ALTERNATIVE LAND USE SOLUTIONS}

\subsection{Settle a comparison layout}

2.2. Identify indicator thresholds (or targets)

2.3. Define alternative management systems (e.g., organic, integrated, biodiversity-friendly, best available technologies etc.)

\section{EVALUATING SOLUTION ALTERNATIVES}

\subsection{Select calculation methods of indicators proportional to the evaluation purpose}

\subsection{Measure indicators}

3.3. Aggregate indicators and present results

Figure 1. Agro-environmental sustainability information system procedural phases (modified from Pacini et al., 2011). 
tive land management options in a Food and Agriculture Organisation (FA0, 2001) worldwide study as described in El-Hage Scialabba et al. (2012). The definitions of the agro-ecosystems properties used for sustainability assessment are reported in Figure 2; they were withdrawn from ecology theory and refined according to how they are referred to in this paper. Indicators of functional properties were further grouped into four categories corresponding to ecosystems functions as defined by De Groot et al. (2002) and the Millennium Ecosystems Assessment (2005): regulation, habitat, production and information functions.

\section{Phase 2. Alternative land use solutions}

The AESIS was developed not only to assess the sustainability of land use options but also to evaluate possible alternatives. The first step of this process consisted of designing a comparison layout where current practices under evaluation were compared with different management systems and with scientifically determined sustainability thresholds (sub-phase 2.1). The thresholds are identified for each single indicator. They are part of the solution to the sustainability problem and determine the extent to which decision-makers change their strategies in order to attain the goals they represent (sub-phase 2.2). In the case of Circolo Golf Ugolino the comparison layout included the comparison with a VF as previously defined (sub-phase 2.3) as well as comparisons of both land use alternatives with thresholds.

\section{Phase 3. Evaluating alternative solutions}

In this phase of the evaluation procedure, the calculation methods of the indicators were selected following a criterion of proportionality to the evaluation purpose (sub-phase 3.1). For instance, indicator processing methods for policy auditing have to be applied to a large number of farms and as such may be based on simple presence/absence observations, whereas some indicators for research and policy planning are calculated for selected representative farms by applying complex, ecological-environmental models with high data input requirements. In the two land use options under survey we chose to apply a combination of in-field observations and simulation modelling.
Finally, indicators were measured (sub-phase 3.2), subsequently aggregated and results were presented (sub-phase 3.3). For the present case-study we integrated indicator results by applying an aggregation framework already validated and applied for sustainability impact assessment at European (EU) and regional levels as in Paracchini et al. (2011). The framework includes land use functions producing ecosystems services and goods and aggregates corresponding indicators based on a multi-criteria linear additive model and sustainability ranges used for indicator normalisation. Indicator aggregation was performed under three different weighting scenarios so to carry out a targeted sensitivity analysis: i) scenario with complete compensation allowed among all of the indicators; ii) scenario considering only classical agronomic-environmental indicators belonging to the physical dimension (soil erosion, environmental pesticide risks, nitrogen leaching, water use), with complete compensation allowed among all of the indicators; iii) scenario with weights attached to sustainability dimensions decided a priori and dimensions considered to be equally weighted, with compensation allowed within a single sustainability dimension, but not among the dimensions, as suggested by Munda (2004).

\section{Results and discussion}

In the next sections, the results of the case-study application are presented by following the AESIS process, as reported in Figure 1, for most significant steps.

\section{Phase 1. Definition of the sustainability issues}

The definition of local sustainability issues was initiated from the review of the regional situation given by the 2014 report on the state of the environment in Tuscany (Regione Toscana, 2015; sub-phase 1.1). In subphase 1.2 we have extrapolated detailed critical points for the agricultural sector from general sustainability issues in Tuscany, as follows. This phase is fundamental to reach a good compromise between

\footnotetext{
Structural properties

- Diversity is given by the number of different components and processes present in the system and their relative abundance. It includes among others biodiversity of genes, species and ecosystems, as well as the diversity of income sources and knowledge, traditional and scientific.

- Coherence provides measures of the numbers and strengths of the connections and flows among components and processes within the system. It considers ecological balance, economic integration and household labour, and seeks to minimize trade-offs and maximize synergies.

- Connectedness is similar to coherence, but concerns the connections with components outside the agroecosystem. It includes, among others, trans-boundary pollution and the production system connectivity with external waterways and habitats; integration of farm business in the supply chain and independence from exogenous factors; and the participation of producers in social networks and institutions.
}

\section{Functional properties}

- Capacity is the average performance level of a state variable in the system, e.g., the quantity of production of foods, biofuels, fibres, timber and other ecosystem goods and services that can be obtained from a unit of inputs (water, land, biodiversity, energy, nutrients and labour).

- Stability is the capability of the system to remain close to stable states of equilibrium when facing normal variations, and is reflected in the frequency and amplitude of fluctuations in the state variables.

- Resilience refers to the aptitude of the system to maintain its performance defined by capacity and stability after a disturbance or long-term or permanent changes in its environment or internal conditions, including both environmental and macro-economic risks.

Figure 2. Agro-ecosystem properties of the conceptual framework for sustainability assessment of land use options (modified from ElHage Scialabba et al., 2014). 
the will to keep a holistic perspective of agro-ecosystem functioning and the need to concentrate on problems at stake under current pedoclimatic and production conditions.

According to the report, $30 \%$ of agricultural land is subject to erosion phenomena, of which $13 \%$ is classified at high erodibility potential. Because erosion is highly affected by stable pedological conditions, corresponding trends are mainly attributable to agronomic practices including, e.g., cover cropping, hydraulic systems and management of crop residues. Considering pesticides in food and water, although all samples in the last reporting period were found to be regular, $35 \%$ of food, $25 \%$ of surface water and $9 \%$ of underground water samples showed pesticide residues. The level of pollution from macrodescriptors indicator, including among other information on phosphorous, dissolved oxygen, ammoniacal and nitrate nitrogen, indicated potential eutrophication in $25 \%$ of surface waters. The $58 \%$ of underground water bodies were found to be in poor chemical state or at risk due to nitrogen substances originated from agricultural activities. These data witness the importance of soil erosion, pesticide risks, water eutrophication and quality in the abiotic domain of regional agro-ecosystems.

Although the Tuscany report on the state of the environment does not take into account biodiversity in agricultural land, its importance in the ecological domain of agro-ecosystems is transversally acknowledged throughout all states of EU with special reference to the ecological focus areas of the greening payment of the 2014-20 CAP.

Besides EU, region and sometimes-even local (e.g., water availability) critical points in the environmental (abiotic and ecological) domains of agro-ecosystems, there are production and social issues that are potentially conflictual and need to be contextualised in the present exercise on golf activities in order to keep a holistic perspective for integrated sustainability assessment. In a world with 850 million under-nourished people, in a country that is not self-sufficient for food, is it sustainable to allocate land for recreation instead of for food production? In a country with total and youth unemployment rates of 12 and $40 \%$, respectively, is it (un)sustainable to renounce to portions of food production and environmental health in exchange for jobs?

Identification of environmental critical points relevant for the agricultural sector in the region are reinforced by the potential impact due to fertilization, irrigation and pest management intensive techniques adopted at CGU (Table 1). Thereafter, corresponding measurable indicators were chosen (Figure 3) based on the conceptual framework in

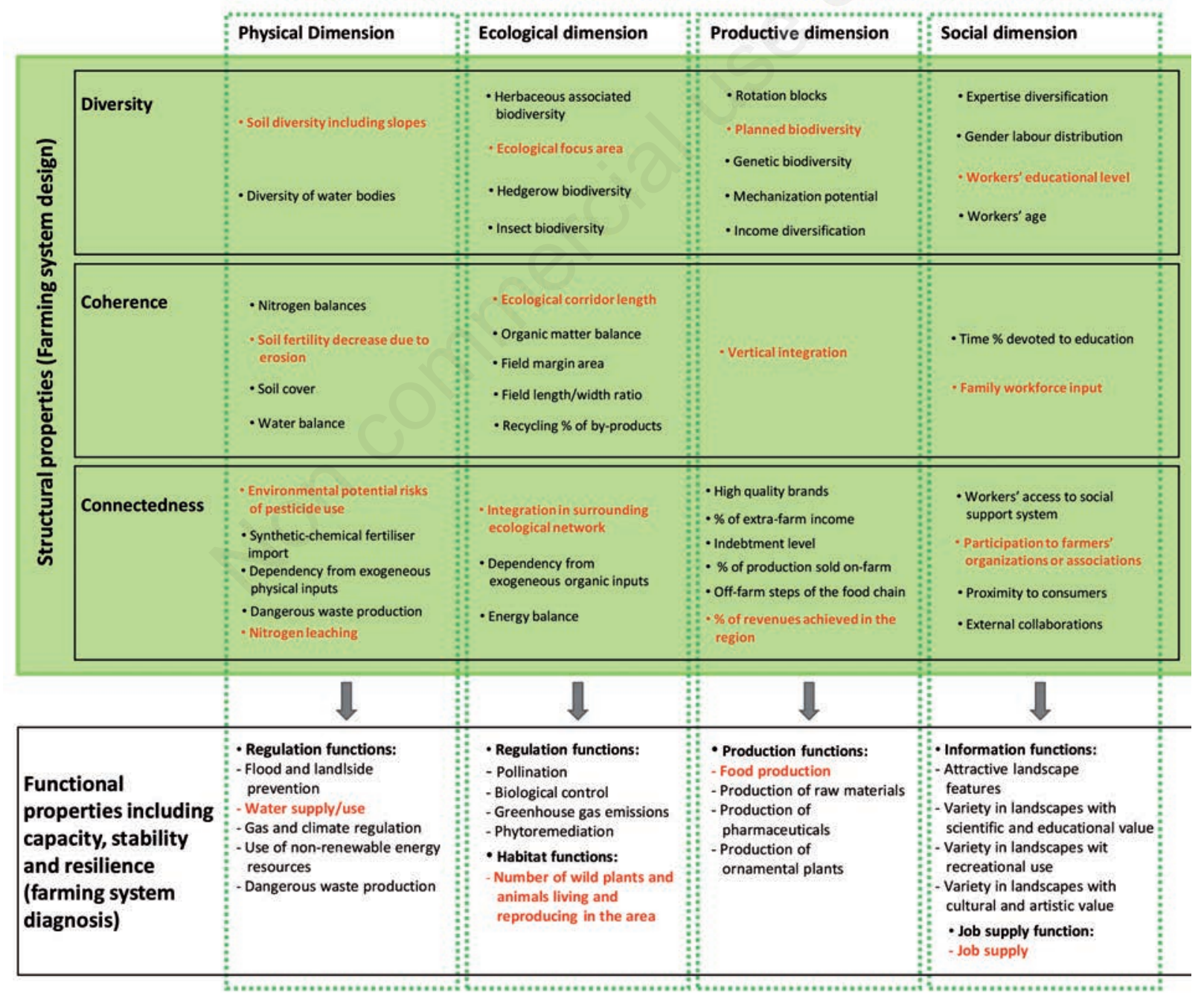

Figure 3. Agro-Environmental Sustainability Information System sub-phase 1.3 choose indicators. Indicators selected for further analysis are reported in red bold. Indicators of functional properties were additionally grouped into categories corresponding to ecosystems functions as defined by De Groot (2002) and the Millennium Ecosystems Assessment (2005), and a function of job supply. 
Figure 2 (sub-phase 1.3). In the first instance, authors chose a number of indicators covering the whole of agro-ecosystem properties and dimensions based on scientific and expert knowledge. In this step it was important to privilege indicators having a direct link with sustainability issues and detailed critical points previously identified. However, additional indicators apparently disconnected with them were chosen in order to keep a holistic perspective and account for potential trade-offs among sustainability dimensions and properties.

Indicators of functional properties were further grouped into the four Millennium Ecosystems Assessment categories. Given the outstanding relevance of job placement in times of economic crisis, we also included an indicator representing the function of job supply that can be enforced by rural enterprises.

Ideally, an exhaustive set, made of hundreds of indicators, would supply a perfect representation of the agro-ecosystems under study, but probably this would happen at an unbearable cost. Hence, following the proportionality principle, and considering the scale of the analysis, only one indicator for each combination of agroecosystem property and sustainability dimension (physical, ecological, productive and social) was selected for further analysis. To simplify the application of the conceptual framework and keep the total number of indicators close to costeffective standards, the three functional properties were assembled in one group and only one indicator was selected as representative for each sustainability dimension. In this way we were able to decrease as much as possible the total number of indicators (16) while keeping a holistic perspective. Exceptionally, two indicators were chosen for physical connectedness (i.e., environmental potential risks of pesticide use and nitrogen pollution) in order to account for both these two aspects as highlighted by phases 1.1 and 1.2 , which made the total number of selected indicators amount to 17 .
In a nutshell, concepts leading the phase of indicator selection were: i) ability to represent agro-ecosystem properties, sustainability dimensions (holistic perspective); ii) ability to represent ecosystems functions; iii) EU proportionality principle (cost-effectiveness); and iv) avoid double-counting. Concerning point iv), double counting is a recurrent problem in financial information systems and its importance is broadly acknowledged but can hold relevance also in sustainability assessment, e.g., we did not select energy indicators and greenhouse gas emissions due to their high correlation with nitrogen pollution (synthetic-chemical fertilisers have a high energy content and their production causes emissions) and soil erosion indicators (soil erosion depends among other factors from energy consuming tillage operations, also causing emissions). The same rationale applies to pollination and bio-control on the one hand and ecological focus area on the other. Sub-phase 1.3 has strong implications in terms of the final results of the analysis as choosing one indicator instead than another can bias sustainability assessment. Under this perspective, it is important that the selection of indicators is as much as possible objective, not driven by biasing elements such as data availability, land use consolidated patterns and preferences, etc.; in our case we used a theoretically-based conceptual framework without considering at this stage sustainability assessment layout and data availability. As a result of this procedure, we anticipate further selection of the list of 17 indicators in the following AESIS steps.

\section{Phase 2. Alternative land use solutions}

The sustainability issue at stake is if golf is a sustainable land use option for Tuscan inland hilly areas. To verify that, we designed a comparison layout including a virtual arable farm (see description in the

Table 1. Ordinary fertilization, irrigation and pest management programs performed on different sections of golf course.

\begin{tabular}{|c|c|c|c|c|c|c|c|c|}
\hline \multirow[b]{2}{*}{ Turf area } & \multirow[b]{2}{*}{$\begin{array}{l}\text { Area } \\
\text { (ha) }\end{array}$} & \multirow[b]{2}{*}{$\frac{N}{\left(\mathrm{~kg} 100 \mathrm{~m}^{-2}\right)}$} & \multicolumn{2}{|c|}{ Fertilization } & \multirow[b]{2}{*}{$\begin{array}{c}\text { Number } \\
\text { of interventions } \\
\text { per year }\end{array}$} & \multicolumn{2}{|c|}{ Irrigation } & \multirow{2}{*}{$\begin{array}{l}\text { Pest management } \\
\text { Type of active } \\
\text { ingredient } \\
\text { (pest in table note) }\end{array}$} \\
\hline & & & $\begin{array}{c}\mathrm{P}_{2} \mathrm{O}_{5} \\
\left(\mathrm{~kg} 100 \mathrm{~m}^{-2}\right)(\mathrm{kg}\end{array}$ & $\begin{array}{l}\mathrm{K}_{2} \mathrm{O} \\
\left.100 \mathrm{~m}^{-2}\right)\end{array}$ & & $\mathrm{mm}$ & $\begin{array}{c}\text { Number } \\
\text { of interventions } \\
\text { per year }\end{array}$ & \\
\hline $\begin{array}{l}\text { Greens/ } \\
\text { collars }\end{array}$ & 1 & 1.88 & 0.96 & 1.83 & 20 & 435 & 135 & $\begin{array}{l}\text { Propiconazole, } \\
\text { prochloraz, }\end{array}$ \\
\hline Tees & 0.7 & 1.82 & 0.30 & 0.88 & 6 & 410 & 135 & clorpirifos-metile $^{\#}$ \\
\hline $\begin{array}{l}\text { Fairways/ } \\
\text { surrounds }\end{array}$ & 13 & 1.36 & 0 & 0.40 & 4 & 330 & 115 & Dicamba, mecocrop $\$$ \\
\hline
\end{tabular}

${ }^{*}$ Dollar spot (Sclerotinia homeocarpa); ${ }^{\circ}$ fusariosis (Fusarium spp.); ${ }^{\sharp}$ crane fly and owlet moths, (Tipulidae and Noctuidae spp., respectively) in green, collars and tees; ${ }^{\S}$ weeds in fairways and surrounds.

Table 2. Sustainability thresholds, targets and ranges.

\begin{tabular}{|c|c|c|c|c|}
\hline Indicator & Sustainability threshold/target & Type & Source* & Sustainability range \\
\hline Soil erosion & $1.4 \mathrm{t} \mathrm{ha}^{-1}$ & $\operatorname{Max}$ & (a) & $1.4-5.0$ \\
\hline Environmental potential risks of pesticide use & 16 EPRIP score/ha ${ }^{-1}$ & $\operatorname{Max}$ & (b) & $0-16$ \\
\hline Nitrogen leaching & $27 \mathrm{~kg} \mathrm{ha}^{-1}$ & $\operatorname{Max}$ & (c) & $10-27$ \\
\hline Water use & $107 \mathrm{~mm}$ & $\operatorname{Max}$ & (d) & $0-107$ \\
\hline Ecological focus area & $5 \%$ & Min & (e) & $5-50$ \\
\hline Ecological corridor length & $60 \mathrm{~m} \mathrm{ha}^{-1}$ & Min & (f) & $60-120$ \\
\hline Planned biodiversity & 4 rotation blocks & Min & (e) & $4-8$ \\
\hline Portion of revenues achieved from local end users & $50 \%$ & Min & (g) & $50-100$ \\
\hline Food production & $4.657 \mathrm{Gcal} \mathrm{ha}^{-1} \mathrm{AAU}$ & Min & (h) & $4.657-9.314$ \\
\hline Job supply & $13.5 \mathrm{ha}^{-1} \mathrm{AAU} / \mathrm{LU}^{\circ}$ & $\operatorname{Max}$ & (i) & $1.0-13.5$ \\
\hline
\end{tabular}

*Source legend: (a) Verheijen et al., 2009; (b) Trevisan et al., 1999, EU Directive 91/414; (c) calculated from the limit for drinking water of $50 \mathrm{mg} / \mathrm{L}$ of EU Directive 91/676, considering local pedo-climatic conditions; (d) based on groundwater recharge calculated from Civita, 1994; (e) Vereijken, 1999, CAP green payment requirement; (f) Schotman, 1988; (g) settled by the authors; (h) calculated based on human energy requirements (FAO, 2001) and Italian agricultural area used; (i) calculated based on labour intensity for arable crops from ISTAT (2013); ${ }^{\circ}$ following the European System of Accounts. EPRIP, environmental potential risk indicator for pesticides; AAU, agricultural area used; LU, labour unit. 
methodology section) as a reference of the area (sub-phase 2.1). This comparison layout implied further selection of indicators. The indicator of soil diversity was discarded because the VF was hypothesized on the same land of CGU, neutralising corresponding results. Social indicators of education, family workforce and participation to farmers' organizations, as well as vertical integration (production dimension), were impossible to be estimated for the specific type of the VF, i.e. an arable farm of 30 ha in inland Tuscany hilly areas. Integration in surrounding ecological network depends on singular entrepreneurial choices and was also impossible to be estimated. Number of wild plants and animals living and reproducing in the area could not be calculated because of the same reason of previous indicators, and probably would not be worthy anyway to be measured for such a small stretch of land. Although these indicators were cancelled for following AESIS steps, we still claim their importance both in terms of transparency of the indicator selection process and overall results discussion, and in terms of pointing out the limitations to be posed to the extent of application of the analysis. Besides the farm comparison, comparisons of single land use options with environmental, production and social sustainability thresholds/targets were settled concerning the ten indicators left (Table 2, sub-phase 2.2).

\section{Phase 3. Evaluating alternative solutions}

In this phase, calculation methods of indicators were selected that met the requirements of the present type of application purpose (subphase 3.1). One procedure was selected for each indicator selected in sub-phases 1.3 and 2.1. The indicator method sources, as well as the descriptions are shown in Table 3.

Table 3. Calculation methods of indicators.

\begin{tabular}{|c|c|c|}
\hline Indicator & Method & Method source \\
\hline Soil erosion & Revised universal soil loss equation (RUSLE) module in CROPSYST model & $\begin{array}{l}\text { Stöckle et al., 2003; } \\
\text { USDA-ARS, 2014a }\end{array}$ \\
\hline Environmental potential risks of pesticide use & Environmental potential risk indicator for pesticides (EPRIP) yardstick & Trevisan et al., 2009 \\
\hline Nitrogen leaching & CROPSYST model & Stöckle et al., 2003 \\
\hline Water use & Water used for irrigation & UN-Water, 2014 \\
\hline Ecological focus area & $\begin{array}{l}\text { Fallow land, terraces, agro-forestry areas, perimetric wood areas, } \\
\text { crops, afforestation land, cover crops, nitrogen-fixing crops } \\
\text { excluded buffer strips }\end{array}$ & EU Regulation 1307/2013 \\
\hline Ecological corridor length & Length of hedges and grass strips (including rough) & Vereijken, 1999 \\
\hline Planned biodiversity & Number of rotation blocks & Vereijken, 1999 \\
\hline Portion of revenues achieved from local end users & Calculated from CGU records and estimated based on expert-knowledge & Elaborated from the authors \\
\hline Food production & $\begin{array}{l}\text { Calculated based on energy content of sunflower and wheat grains } \\
\text { retrieved from USDA national nutrient database for standard reference }\end{array}$ & USDA-ARS, 2014b \\
\hline Job supply & Calculated from CGU records and labour intensity of arable crops & ISTAT, 2013 \\
\hline
\end{tabular}

CGU, Circolo Golf Ugolino; USDA, United States Department of Agriculture.

Table 4. Results of indicators and aggregation under three different weighting scenarios

\begin{tabular}{|c|c|c|c|c|c|c|c|c|c|}
\hline Indicator & $\mathrm{Va}$ & & TV & & & ated, no & ialised & score & \\
\hline & & & & Scen & o a)* & Scer & io b $)^{\circ}$ & Scent & io c) $)^{\#}$ \\
\hline & CGU & VF & & CGU & VF & CGU & VF & CGU & VF \\
\hline Soil erosion $\left(\mathrm{t} \mathrm{ha}^{-1}\right)$ & 1.6 & 5.0 & 1.4 & -0.05 & -1.01 & -0.05 & -1.01 & -0.01 & -0.25 \\
\hline Environmental potential risks of pesticide use (EPRIP score ha-1) & 4.0 & 4.5 & 16 & 0.75 & 0.72 & 0.75 & 0.72 & 0.19 & 0.18 \\
\hline Nitrogen leaching $\left(\mathrm{kg} \mathrm{N} \mathrm{ha}^{-1}\right)$ & 117 & 49 & 27 & -5.29 & -1.26 & -5.29 & -1.26 & -1.32 & -0.32 \\
\hline Water use (mm) & 380 & 0 & 107 & -2.55 & 1.00 & -2.55 & 1.00 & -0.64 & 0.25 \\
\hline Physical dimension & & & & -7.14 & -0.55 & -7.14 & -0.55 & -1.78 & -0.14 \\
\hline Ecological focus area (\%total area) & 40 & 5 & 5 & 0.78 & 0.00 & n.c. & n.c. & 0.39 & 0.00 \\
\hline Ecological corridor length (m ha $\left.{ }^{-1}\right)$ & 110 & 0 & 60 & 0.83 & -1.00 & n.c. & n.c. & 0.42 & -0.50 \\
\hline Planned biodiversity (no. rotation blocks) & 1 & 2 & 4 & -0.75 & -0.50 & n.c. & n.c. & -0.25 & -0.17 \\
\hline Ecological dimension & & & & 0.86 & -1.5 & 0.00 & 0.00 & 0.56 & -0.67 \\
\hline Portion of revenues achieved from local end users (\%) & 40 & 0 & 50 & -0.20 & -1.00 & n.c. & n.c. & -0.10 & -0.50 \\
\hline Food production $\left(\mathrm{Gcal} \mathrm{ha}^{-1}\right)$ & 0.0 & 6.4 & 4.7 & -1.00 & 0.37 & n.c. & n.c. & -0.50 & 0.19 \\
\hline Production dimension & & & & -1.2 & -0.63 & 0.00 & 0.00 & -0.60 & -0.31 \\
\hline Job supply (AAU LU-1) & 3.8 & 33.3 & 13.5 & 0.78 & -1.58 & n.c. & n.c. & 0.78 & -1.58 \\
\hline Social dimension & & & & 0.78 & -1.58 & 0.00 & 0.00 & 0.78 & -1.58 \\
\hline Sustainability aggregated index (no.) & & & & -6.70 & -4.26 & -7.14 & -0.55 & -1.04 & -2.70 \\
\hline
\end{tabular}


Indicators were measured and relevant results are shown in Table 4 (sub-phase 3.2). The golf course achieved sustainable performances for 4 of 10 indicators including environmental pesticide risks, ecological focus area and corridors, and job supply. The arable crop system achieved sustainable performances also for 4 of 10 indicators including environmental pesticide risks, water use, ecological focus area and food production. VF modelled results of soil erosion, environmental potential risk indicator for pesticides (EPRIP) and nitrogen leaching are in line with a number of studies carried out in Tuscany under comparable production and pedo-climatic conditions (Pacini et al., 2011; Merante et al., 2015; Pacini et al., 2015).

Concerning direct comparisons of CGU with VF, CGU achieved better performances for 6 of 10 indicators, including soil erosion (1.6 and 5.0 $\mathrm{t} \mathrm{ha}^{-1}$, respectively), due to permanent soil cover by grassland, EPRIP (4.0 and 4.5 EPRIP score ha ${ }^{-1}$ ), ecological focus area (40 and 5\%), due to specific importance given at Ugolino golf course to ecological infrastructures, ecological corridor length (110 and $0 \mathrm{~m} \mathrm{ha}^{-1}$ ), due to extended CGU rough sectors, portion of revenues achieved from local end users (40 and 0\%) and job supply (3.8 and 33.3 agricultural area used labour unit ${ }^{-1}$ ).

CGU showed very low performances in terms of nitrogen leaching (117 $\mathrm{kg} \mathrm{N} \mathrm{ha}^{-1},+239 \%$ and $+433 \%$ as compared to VF and threshold, respectively) and water use $(380 \mathrm{~mm},+355 \%$ as compared to threshold) and this is in line with environmental concerns as reported in the introduction.

However, when aggregating indicators into one sustainability index (sub-phase 3.3, Table 4), because of notably negative performances in terms of nitrogen leaching and water use, the golf course index was found to be $36 \%$ lower than the sustainability index of the virtual arable farm (weighting scenario a), $-6.74 v s-4.26$, respectively). This difference reached the considerable level of $92 \%$ under weighting scenario b, when only classical environmental-agronomic indicators of the physical dimension were considered ( $-7.14 v s-0.55$, respectively). Results reversed when imposing equal weights to the four sustainability dimensions (weighting scenario c), which allowed positive performances of the golf course in terms of ecological and social dimensions $(+0.56$ and +0.78 , respectively) to consistently compensate negative results in terms of physical and production dimensions $(-1.78$ and -0.60 , respectively). This was possible only because of the relative reduction of the impact of nitrogen leaching (from -5.29 to -1.32 ) and water use (from -2.55 to 0.64 ).

Our approach reflect the importance of an overall assessment of all components (ecological, recreational, socioeconomic, etc.) that affect management of a golf course and in this way it is consistent with findings of Dai et al. (2016), who pointed out that ecological benefits produced by golf course are higher than dis-services, in terms of financial accounting. These ecological services can also be enhanced by particular management reserved to rough areas that can play an important role in conservation of particular environments with typical plants and to improve pollination activity (Dobbs and Potter, 2016).

\section{Conclusions}

Our work produced interesting comparison between two very different kinds of land use that have been characterized under different options. The comparison performed by means of an overall approach framework (AESIS) demonstrated to be efficient in pointing out benefits and negative aspects linked to the two alternatives here examined.

In particular, from a methodological point of view, AESIS framework proved to be a practical and adaptive tool that during our work was used under three scenario characterized by different features. Modularity of
AESIS permitted in this way several simulations with different weights that produced different results in the comparison. Thus, it is important to stress that the framework does not follow a rigid scheme but it can rely on different indicators to be chosen according to different aims. This can be an efficient method to compare possible land destination options, a case that can happen in a planning committee of a municipality to which is assigned the duty to deliver the permission for a golf course construction.

Considering results of the study, golf course showed to have a significant impact on some physical-environmental characteristics but on the other side it performed in a better way than the alternative ordinary farm in some features concerning both ecological-environmental and socioeconomic domains, confirming that a proper assessment of sustainability can be performed only with a holistic approach that comprises a wide range of different issues.

\section{References}

Baldi A, Lenzi A, Nannicini M, Pardini A, Tesi R, 2013. Growth and nutrient content of hybrid bermudagrass grown for nursery purposes at different nitrogen, phosphorus, and potassium rates. Horttechnology 23:347-55.

Bigelow CA, Walker KS, 2008. Annual nitrogen fertility regime affects appearance and soil loss for three cool season lawn species. Proc. 1st Europ. Turf. Soc. Conf., Pisa, Italy, pp 47-8.

Bowman DC, Cherney CT, Rufty TW, 2002. Fate and transport of nitrogen applied to six warm-season turfgrasses. Crop Sci. 42:833-41.

Dai Z, Puyang X, Han L, 2016. Using assessment of net ecosystem services to promote sustainability of golf course in China. Ecol. Indic. 63:165-71.

De Groot RS, Wilson MA, Boumans RMJ, 2002. A typology for the classification, description and valuation of ecosystem functions, goods and services. Ecol. Econ. 41:393-408.

Dobbs EK, Potter DA, 2016. Naturalized habitat on golf courses: source or sink for natural enemies and conservation biological control? Urban. Ecosyst. [Epub ahead of print].

Easton ZM, Petrovic AM, 2005. Impact of organic and mineral fertilizers on run-off from turf. Bet. Crops 89:16-7.

El-Hage Scialabba N, Khor M, Le Cotty T, Pacini C, Zileki S, Groppo P, Hill C, Lipper L, McMahon P, Meybeck A, Raymond R, 2012. Greening the economy with agriculture. Food and Agriculture Organisation (FA0), Rome, Italy.

Food and Agriculture Organisation (FA0), 2001. Human energy requirements. Report of a Joint FAO/WHO/UNU Expert Consultation, Rome, 17-24 October 2001. FAO-Food and nutrition technical report series 1. Food and Agriculture Organisation (FA0), Rome, Italy.

Gaetani M, Lulli F, Andreucci A, Masini A, Vittori G, Volterrani M, 2013. Sprouting and plant regeneration capability in saline conditions of seashore paspalum, manilagrass, and hybrid bermudagrass stolons. Propag. Ornam. Plants 13:57-64.

Geren H, Avcioglu R, Curaoglu M, 2009. Performances of some warmseason turfgrasses under Mediterranean conditions. Afr. J. Biotech. 8:4469-74.

Giardini L, 2012. L'agronomia per conservare il futuro. $6^{\text {th }}$ ed. Patron ed., Bologna, Italy.

Kir B, Avcioglu R, Demiroglu G, Simic A, 2010. Performance of some cool season turfgrass species in Mediterranean environment: I. Lolium perenne L., Festuca arundinacea Schreb., Poa pratensis L., and Agrostis tenuis Sibth. Turk. J. Field Crops. 12:174-9.

Linse SJ, Mergen DE, Smith JL, Trlica MJ, 2001. Upland erosion under 
a simulated most damaging storm. J. Range. Manage. 54:356-61.

Marchione V, 2008. Performance of several Cynodon dactylon and Zoysia japonica cultivars in southern Italy. Proc. 1st Europ. Turf. Soc. Conf., Pisa, Italy, pp 125-6.

Merante P, Van Passel S, Pacini GC, 2015. Using agro-environmental models to design a sustainable benchmark for the sustainable value method. Agric. Syst. 136:1-13.

Millennium Ecosystem Assessment (MA), 2005. Ecosystems and human well-being: synthesis. Island Press, Washington, DC, USA.

Munda G, 2004. Social multi-criteria evaluation: methodological foundations and operational consequences. Eur. J. Oper. Res. 158:662-77.

Pacini GC, Lazzerini G, Migliorini P, Vazzana C, 2009. An indicatorbased framework to evaluate sustainability of farming systems: review of applications in Tuscany. Ital. J. Agron. 4:23-40.

Pacini GC, Groot JCJ, Bacigalupe F, Vazzana C, Dogliotti S, 2010. Systematic evaluation of indicator sets for farming system diagnosis and design. Proc. $9^{\text {th }}$ Eur. IFSA Symp. "Building sustainable rural futures - The added value of systems approaches in times of change and uncertainty", Vienna, Austria, pp 861-71.

Pacini GC, Lazzerini G, Vazzana C, 2011. AESIS: a support tool for the evaluation of sustainability of agroecosystems. Example of applications to organic and integrated farming systems in Tuscany, Italy. Ital. J. Agron. 6:11-8.

Pacini GC, Merante P, Lazzerini G, Van Passel S, 2015. Increasing the cost-effectiveness of EU agri-environment policy measures through evaluation of farm and field-level environmental and economic performance. Agric. Syst. 136:70-8.

Paracchini ML, Pacini GC, Jones MLM, Pérez-Soba M, 2011. An aggregation framework to link indicators associated with multifunctional land use to the stakeholder evaluation of policy options. Ecol. Indic. 11:71-80.

Piano E, 2005. Inerbimenti e tappeti erbosi nella realtà italiana: motivazioni e finalità per lo sviluppo della ricerca. Proc. Conference
"Inerbimenti e tappeti erbosi per l'agricoltura, l'ambiente e la società", Lodi, Italy, pp 5-20.

Regione Toscana, 2015. Relazione sullo stato dell'ambiente in Toscana 2014. Regione Toscana, Agenzia regionale per la protezione ambientale della Toscana (ARPAT), Firenze, Italy.

Ruiz-Martinez I, Marraccini E, Debolini M, Bonari E, 2015. Indicators of agricultural intensity and intensification: a review of the literature. Ital. J. Agron. 10:74-84.

Seppoloni I, 2014. Valutazione di tappeti erbosi a base di graminacee macroterme a scopi ricreativo-ornamentali. Degree Diss. Università di Firenze, Italy.

Seppoloni I, Staglianò N, Cecchi S, Argenti G, 2015. Performance of warm-season turfgrasses in an area of Central Italy. Adv. Hort. Sci. 29:53-8

Sevostianova E, Leinauer B, 2014. Subsurface-applied tailored water: combining nutrient benefits with efficient turfgrass irrigation. Crop Sci. 54:1926-38.

Trenholm LE, Sartain JB, 2010. Turf nutrient leaching and best management practices in Florida. Horttechnology 20:107-10.

Turgeon AJ, 2008. Turfgrass management. 8th ed. Pearson Education International, Upper Saddle River, NJ, USA.

USDA-ARS (United States Department of Agriculture - Agricultural Research Service), 2014a. "Revised universal soil loss equation (RUSLE) - Welcome to RUSLE 1 and RUSLE 2". Available from: http//www.ars.usda.gov/Research/docs.htm?docid=5971

USDA-ARS (United States Department of Agriculture - Agricultural Research Service), 2014b. National Nutrient Database for Standard Reference, Release 28. Available from: http:/www.ars.usda.gov/ Services/docs.htm?docid=8964

Volterrani M, Magni S, 2007. Il tappeto erboso ieri, oggi e domani. In: I quaderni C.I.R.A.A., Tappeti erbosi. Aspetti tecnici, ambientali e paesaggistici. Felici Editore, Pisa, Italy, pp 29-36. 